811.163.41'367.623

811.163.41'373.6

https://doi.org/10.18485/sj.2020.25.1.39

ДАНИЈЕЛА С. СТАНИЪ ${ }^{*}$

Институт за српски језик САНУ Београд
Оригинални научни рад

Примљен: 15. 10. 2019.

Прихваћен: 15. 01. 2020.

\title{
О РУДИНИЦИ И ХОМОНИМИЈИ ДВА ПРАСЛОВЕНСКА ПРИДЕВА У СРПСКОМ ЈЕЗИКУ**
}

У раду се анализирају два историјски хомонимична придева у српском језику, $p y \partial^{1}$ са колористичким значењем и $p y \partial^{2}$ са неколористичким значењем. На основу етимолошких, лексикографских, дијалектолошких, фолклористичких и географских података настојали смо да прикажемо како функционише семантичка кохезија међу дериватима сваког од појединачних хомонима и како придевски деривати под међусобним утицајем добијају своја данашња значења.

Кључне речи: придеви, деривати, етимологија, лексикографија, дијалектологија, фолклор, географија.

\section{1. ПОСТАВЉАЬЕ ПРОБЛЕМА}

1.1. Циљ овог рада је расветљавање хомонимије као историјске појаве и приказивање њених последица на стање у савременом српском језику. Већина лингвиста приступа хомонимији са синхроног становишта и ми се слажемо са тим. Овим радом ћемо дати примере лексема из савременог српског језика које су последица укрштања сема које су у прасловенском припадали хомонимичним придевима.

*danijela.stanic@isj.sanu.ac.rs

${ }^{* *}$ Рад је настао у оквиру пројекта 178009 Лингвистичка истраживања савременог српског књижевног језика и израда Речника српскохрватског књижевног и народног језика САНУ, који у целини финансира Министарство просвете, науке и технолошког развоја Републике Србије. 
Најпре ћемо дефинисати хомонимију. „Хомонимија није системска појава. Она је само чињеница, факат у лексичком систему. Она је постојање и могућност постојања двају или више диверзних семантичких садржаја у формално, по спољашњем изгледу истоме облику.” (Гортан Премк 1997: 150). Међу невеликим проучаваоцима овог језичког феномена на нашем говорном подручју издвојићемо поред Д. Гортан-Премк још и Б. Тафру, Д. Шипку и Р. Драгићевић. Сви се ови аутори слажу у ставу да је најважнији узрок хомонимије распад полисемске структуре, са том разликом што Д. Шипка при њеном објашњењу примењује етимолошки метод.

1.2. Међутим, поставља се питање шта је са судбином полисемије првобитно историјски хомонимних лексема, по ком критеријуму оне даље развијају деривацију, нове лексеме напуштају семантичко језгро, везују се за природне и друштвене реалије, радње, процесе и стања и да ли међу њиховим дериватима постоји одређена семантичка и творбена кохезија. Такође, можемо поставити и питање шта се дешава са другим лексемама, новијег историјског пресека од првобитног хомонимијског пара, које, такође, припадају истој граматичкој класи као лексеме „родитељи”, да ли оне проширују или спецификују своје семантичко поље у односу на полазне лексеме.

1.3. Мотив за ово лингвистичко истраживање пронашли смо у архаичној и на први поглед загонетној лексеми, која је своју двоструку употребу нашла у поезији Ерлангенског рукописа (даље ЕР). Реч је о лексеми рудиниияа.

Најпре ћемо дати уводне напомене о самој збирци. Ерлангенски рукопис пронађен је 1913. године у Универзитетској библиотеци немачког града Ерлангена, где се и данас чува. Герхард Геземан га је објавио дипломатички 1925. год., и пропратио у предговору једном свеобухватном мотивском, језичком, ортографском анализом. На основу историјске заснованости појединих епских песама, на основу личности и локалитета који се у њима појављују, по типу хартије и повеза рукописа, који је „био укоричен у макулатурне листове неког немачко-аустријског црквеног календара из год. 1733.", Геземан га је приближно датирао на доба око 1720. године (ЕР: XIII-XXI). Можемо рећи да је највећи и најстарији поуздано датирани зборник српских народних песама, који, заједно са бугарштицама, представља најважније врело наше народне баштине, настале готово сто година пре национално-историјског романтичарског буђења и пре штампања Вукове „Пјеснарице” 1814. године.

Рукопис је писан, по Геземановим речима, обичном ћирилицом, тзв. „дипломатском”. Претпоставка је да збирка представља странчев (највероватније каквог Немца) препис песама са замишљеног концепта. Збирку још одликује тематска, стилска, метричка и дијалекатска разуђеност и некохерентност присутна чак и у оквиру једне песме, тако да су Геземан, као и потоњи истраживачи, закључили да се ради о вишеструкости народног певача. 
Због велике старости збирке, Ерлангенски рукопис је захвалан за етимолошка и фолклористичка истраживања.

4 Задржаћемо се на, сада већ архаичној, именици рудиница, која је забележила двоструко значење у Ерлангенском рукопису, па на основу њене идиолекатске употребе могли бисмо да изведемо закључак о јединственом певачу песама бр. 212 и бр. 217. Представићемо поетски контекст у коме је дата именица развила своја значења:
„Расла трава рудиница по њој ружица.
На њој Јован коња пасе ружу трга" (бр. 212) и
„С оне стране рудинице по њој ружице.
Чувала ми лепа Мара из мајкина двора.
Навади м' се Вук Бранкович с коњма на ружу,
те потлачи рудинииу и црвену ружу.
Говорила лепа Мара из мајкина двора:
„Који оно Остроклобић у мојој ружи,
те потлачи рудинииу и црвену ружу?” (бр. 217).

5 Ишчитавајући песме поставили смо питање на шта је тачно певач мислио употребивши лексему рудиница. У одређивању семантике ове именице поћи ћемо од Речника МС. Ту стоји дефиниција за рудинииу: „дем. и хип. од рудина”, а под рудина следећа дефиниција: „необрађено земљиште обрасло травом, утрина, тратина”.

\section{2. ЕТИМОЛОГИЈА ХОМОНИМСКИХ ПРИДЕВА РУД ${ }^{1}$ И РУД И СТАњЕ У ДИЈАЛЕКТИМА}

2.1. Пошто нам оваква дефиниција није у потпуности одговарала контексту песме, проверили смо и етимологију прасловенског придева руд. Наиме, ради се о хомонимији између колористичког придева rûd ${ }^{1}$ и неколористичког придева rûd ${ }^{2}$. Да бисмо расветлили дати проблем, ближе ћемо објаснити порекло и деривациона гнезда оба придева.

2.2. Колористички придев rûd ${ }^{1}$ је индоевропски, балтословенски, свесловенски и прасловенски придев у значењу „риђ, црвен, црвенкаст”. Корен je *reudh-, у превоју перфектума *roudh-. Самогласник u настао је од индоевропског двогласа ou, као у лит. Raũdas, у значењу „црвен (коњ)”. Исти вокал налази се још у придевима румен и рус. Овај прасловенски придев творбено адаптиран утицао је на изградњу следећих лексема: у поимениченом облику руда у значењима „црвени купус” и „минерал”, поименичено са суфиксима -њача у рудњача за „гљиву” и ,јагоду” и суфиксом -ача у рудача за „црвенкасту јабуку". Од њега се твори глагол рудјети, који се првобитно односио на грожђе, као и деривационо гнездо оронима рудник, рудар, рудара, рударов, 
рударев, рударски, рударија, рударина, рударница, рударнички, рударство, рудство. Придев је присутан и у топонимији: Рудопоље (Лика), Руда Буква (Ужице), Руда главица, Рудо Брдо (Црна Гора) (Скок 1973: 165).

2.3. Прећи ћемо на неколористички придев rûd². Придев је историјски новијег, прасловенског порекла *rodъ, са полисемијом „кудрав” за косу, вуну, власи, главу, чело и перчин и „растресит, незамршен, мек” за погачу. Овај прасловенски придев утицао је на творбу следећих лексема: у поимениченом облику руда за „честу и коврџаву вуну”, за „име домаћим животињама”, за „планинску траву” и за „црвен купус” (у овом значењу укрштено са колористичким придевом руд), са суфиксом на -bc> -ac у рудаи као „трава која расте по утринама", са суфиксима -ишњача и -њача у рудишњача и рудњача за „врсту гљиве” и „печурку што расте по рудини, виловњачу”, са суфиксима -оњ $а$ u -уља у рудоњ $а$ и рудуља за „име домаћим животињама” и „рудасту вуну". Аугментативи на -етина у рудетина се јављају у географким терминима, за „тратину, утрину, пољану” и у значењу „мека земља” у облику рудина, са суфиксом на -ина. У ономастици Рудина је чест топоним. Деминутив на -иница у рудиница се употребљава са полисемијом „тратине, утрине, рудине” и као „топоним” (Рудиница, уз море, Милна). Деноминални глаголи рудати и рудити значе „коврџати”. Придев је потврђен само у српском, хрватском, словеначком и бугарском (?) (Скок 1973: 165-166).

2.4. Допунићемо етимологију ова два хомонимична придева још неким релевантним подацима везаних за њихов утицај на друге колористичке придеве и за семантику црвене боје. $P y c$ је балтословенски, свеславенски и прасловенски придев настао од истог индоевропског корена као и $р y \partial$, *roudhраширеног помоћу форманта s: *roudh- + so. Придеви рус и руд у фолклору у синтагматским спојевима искључиво се употребљавају уз денотате који означавају длаку: руса коса и руд перчин, и тада они значе „риђ, риђокос”, а нијанса боје коју овај придев означава јесте црвенкастожута (Станић 2015: 65). Придев румен је словенски и прасловенски придев настао додавањем суфикса -mēnъ (-*men) на корен rud- (*roudh-) (Скок 1973: 171). Значење боје овог придева је примарно и повезује се са значењем латинског rumen (гуша) и литванским raumuõ (месо шкољке) (Скок 1973: 173). Придев рујан у значењу „жућкастоцрвен, риђаст, руменкаст” (РМС) налази се још у бугарском, словеначком и чешком језику и нема опште прихваћену етимологију (Скок 1973: 168). Непосредно је изведено из руј, назива за биљку из које се добила (црвенкасто)жута боја. Тај фитоним, с обзиром на своју распрострањеност (јужнословенски, и само још чешки, који је добио из јужнословенског) не може се одвојити од латинског назива за исту биљку Rhus (Безлај 3: 206а). Овај придев нема утврђену етимологију, али га повезују са колористичким придевом руд (Скок 1973: 165, 168). 
2.5. Поуздано упориште за откривање етимологије одређених лексема јесу дијалекти народних говора. У ту сврху смо претражили значења наведених хомонимичних придева $p y d^{1}$ и $p y d^{2}$ у неколико дијалекатских речника.

2.6. Као представнике источнохерцеговачког дијалекта издвојили смо Вуков Српски рјечник (даље Вук, СР) и Речник ужичког говора Ратомира Цвијетића (даље РУГ). Вук од глагола у свом речнику наводи рудјети, рудити и руђети, а од именица рудоња (за вола), рудњача (за печурку) и рудача (за траву) (в. о томе ниже у тексту). Р. Цвијетић у свом речнику издваја следеће лексеме: рудан „име волу”, рудинарка „врста гљиве која расте по рудинама, утринама”, рудиница „мала утрина”, рудиште „налазиште руде”, рудиница „воћка чији су плодови тек зарудели” (Обраше ми рудиницу, не сачекаше да сазри).

2.7. Као представника шумадијско-војвођанског дијалекта издвојили смо Речник српских говора Војводине (даље РСГВ). У њему смо пронашли следеће лексеме: рудити „добијати румену боју зрења, почињати зрети (о воћу); шарати се (о житу)”, зарудити „добити црвену боју (о трешњама, парадајзу и сл.)”, заруђивати „добијати црвену боју”, рудина 1. „Узвишење између две баре, полоја”, 2. „необрађено земљиште обрасло травом”.

2.8. Као представника призренско-тимочког дијалекта издвојили смо Tuмочки дијалекатски речник Јакше Динића (даље ТДР). У њему смо пронашли

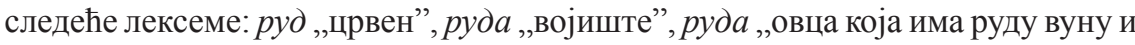
име таквој овци”, рудее се „црвени се”, руденица „земљиште окренуто југу са ретком, ситном вегетацијом, утрина, рудина (чест топоним), рудина „плитко земљиште окренуто југу, по коме је једва порасла ситна трава, пољана, утрина, пашњак, упор. руденица".

\section{3. О ЛЕКСЕМИ РУДИНИЦА}

3.1. Вратимо се на разматране примере из поезије Ерлангенског рукописа. П. Скок, у етимолошком речнику, под трећим значењем наводи „врсту планинске траве" (Скок 1973: 165), што у потпуности одговара наведеној синтагми, трава рудиница, у првој песми. Међутим, поставља се питање да ли је реч само о врсти траве у другој песми и да није у оба случаја реч о контаминацији основа колористичког придева $p y d^{1}$ у значењу „црвенкаст” и неколористичке именице у значењу „врста траве”, која припада неколористичком придеву $p y d^{2}$. Да бисмо одговорили на ово питање, прегледали смо необјављену грађу Речника САНУ за именице рудина и рудиница.

3.2. Лексема рудиница не развија полисемију и лексикографска дефиниција јој у потпуности одговара дефиницији Речника МС. Навешћемо неколико 
најрепрезентативнијих примера: „Пале су патке у слано море, | А препелице у равно поље, | А јеребице у рудинице, | Мале тичице у ломинице” (НП Вук I, 318). „Тако је ишла с њим [Милена] кроз неку густу честу; он је подизао гране рукама да она не би главом за њих закачила... И тако је изведе на неку рудинииу. Око њих шума, густа, мрачна; овде онде тек пробио по који сунчев зрак” (Весел. 17, 271). „Подбочила се та женска страна на то дрво, забодено у влажну ледину, пробио је смртни зној, тешко дише и некако се искривила као да је наумила да се ту, на тој метохијској рудиници, окамени за спомен кад се земља остављала” (Бож. Г. 5,18$)$. „Можда је могао бити један сат до зоре када смо прешли иза брда одакле се више није могао видети логор. У уској рудиници прострли смо своју ћебад и легли” (Ђон. Ј. 3, 182).

3.3. С друге стране, именица рудина има богату полисемију. Номинационо значење дефинисали смо на следећи начин: 1. а. необрађено планинско земљиште обрасло травом које служи обично за испашу, утрина, тратина, ледина: „Ја видех селанце и око њега хитру и здраву сеоску дечицу како трче зеленом ледином, вијају се и један другог обара на меку рудину" (Милорад, Матица 1867,619$)$. „Што год се раније гора развије, а ливаде и рудине наките биљем и цвијећем, па се раније почну челе ројити” (Врч. 5, 54). „Козе су брстиле по лугу, а свиње су пасле по рудини поред пута" (Мил. М. Ђ. 29, 3). „Један део гљива, нпр. смрчци, расту највише по шумама, а друге, нпр. рудњаче, махом по ливадама, утринама и рудинама” (Батут 2,100$)$. „Печурка се налази на тратинама и рудинама у шумама” (Ненад. 1, 33). „Он [Спасоје] гледа... колико његов род, његов мученички сој, има страсти и заноса ... колико расте у висину, издиже се изнад самог себе, колико му камене рудине, брда и планине дају замаха и вере у победу” (Ђур. 5, 63).

Секундарна значења смо дефинисали на следећи начин: 1. б. планинско земљиште претворено у ораницу: „И у рудину прве године узорану може се овасъ сьяти” (Ник. Ат. 3, 116). „Лујетићи прионуше својски да обраде рудину. Била им је с неруке и подалеко, али као присојна новина, кад се засади лозом и стане на род, намириће им труд” (Мат. 13, 201). „Девојће су кроз гору појале.| Од рудину момче оратило: | „Јела, јела, код мене, девојће”” (Јанковић Љ., Дело 10, 432). 1. в. култивисана, уређена травната површина са негованом травом у близини стамбених зграда, башта: „У цветњаку настаје чишћење и уређивање група дрвета и украсног шибља, рудине и стаза” (Влад. Т. 1, 4). „Од тих семена [су у напреднијим земљама] састављали смесе од више подесних трава, које ће једна другу поправљати и допуњавати и то смесе: како за ливаде самокоше и за пашњаке или за рудине по баштама и шеталиштима" (И., 31). Ланчаном полисемијом (Драгићевић Р. 2007: 133) овде бисмо могли да изведемо и још једно секундарно значење са потврдом из Ерлангенског рукописа у ком би дошло до контаминације основа хомонимичног придева pyд у значењу „црвенкаст” и именице руд у значењу „врста траве”: 1. г. башта 
са црвеним цвећем: „С оне стране рудинице по њој ружице. | Чувала ми лепа Мара из мајкина двора. | Навади м' се Вук Бранкович с коњма на ружу, | те потлачи рудинииу и црвену ружу” (ЕР, бр. 217).

3.4. Сличну контаминацију основа налазимо у деривационом гнезду ових двеју хомонимичних лексема, придева и именице, на корпусу преузетом из Вуковог Српског рјечника: рудача - „трава ситна по утринама (из Црне Горе)”, рудњача - „печурка (што расте по рудини?) (у Шумадији)”, рудоњ - „во рудаст”, рујница - „Гљива, уп. сирњаја”. Сматрамо да су рудиница и рудача једна трава и да се вероватно ради о црвенкастој трави, вероватно и таласастој, а овој групи фитонима бисмо могли придодати и руду у значењу „врсте црвеног купуса”, за коју је и Скок П. потврдио да се ради о контаминацији основа (Скок 1973: 165).

Рудина у свом колористичком значењу, а на основу необјављене грађе Речника САНУ, има још једно значење које бисмо сврстали под одвојену хомонимичну одредницу: ,јутарња светлост руменожуте боје”. - „Једва свану. Са истока забијели рудина; живина поче слијетати са седала; свиње загрокташе у оборима; ждријебац његов зарза у ару" (Весел. 17, 218). Из овог значења именице рудина развио се и глагол рудити - „руменити при свитању (о зори)”.

3.5. Дакле, претпостављамо да се контекст песме бр. 217 односи на „башту обраслу црвеним цвећем” и да је ту дошло до метафоричког преноса по колористичкој сличности и то ланчаном реакцијом, почев од траве, преко планинског пашњака, планинске оранице, човеком култивисане баште обрасле црвенкастом травом до баште обрасле црвеним цвећем.

\section{4. ОПШТИ ЗАКљУЧЦИ О ХОМОНИМИЈИ ПРИДЕВА РУД' И РУД}

4.1. На основу прегледане лексикографске грађе, етимолошких и лексикографских података можемо да изведемо општи закључак да је дошло до семантичке кохезије и до преклапања два хомонимична придева, $p y d^{1}$ у значењу „црвен” и руд² у значењу „коврџав” и „растресит, незамршен, мек”.

Географски термин рудина преко врсте траве рудинице путем семантичке

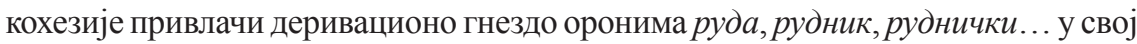
деривациони систем. Као део тог процеса поменуто деривационо гнездо се отрже из прасловенског корена и почиње да означава „унутрашње земљино богатство, намењено експлоатацији”, без нужне семантичке повезаности са колоритом. Дакле, долази до приближавања два оронима, руда, рудник и рудина.

Због природе лингвистичких претпоставки анализирали смо и природу географског терена. Рудине су карактеристичне за кречњачки терен. Распро- 
страњен тип земљишта за кречњачки терен је црвеница или terra rossa. Она се формира по дну увала, вртача и крашких поља. Црвена боја земљишне подлоге може бити и вулканског порекла. По хемијском саставу terra rossa садржи оксиде гвожђа и алуминијума који јој дају црвену боју. Особеност јој је да брзо упија и лако задржава воду, тако да је згодна за формирање пашњачког терена са меком травом и на сувим стаништима, травом тзв. рудиницом. Таква трава, под минералним својствима земље црвенице, и сама добија колористичко обележје, па имамо још један тип семантичког приближавања на релацији ороним $\leftrightarrow$ ороними (црвена руда $\leftrightarrow$ утрина, црвеница $\rightarrow$ утрина $\rightarrow$ трава, тј. црвена руда $\rightarrow$ црвена трава (рудиница)).

Потврду за лексичку претпоставку налазимо у топонимији, јер називи места врло често у себи региструју облик терена и његову специфичну колористичност. Као пример узели смо микротопонимију из ужичког краја: Рудине (Љубање, речица Буковац), Рудине (заселак Јолетићи (Крива Река, речица Криваја)), Рудине (брдо у Кремнима, источна страна котлине), Рудиште (Скржути, заселак Топаловићи), Рудински брег (заселак Подгорица, Бранешци, Шљивовица), Црвене стене (пашњак у Жељинама), Црвенски вир (Биоска), Алина вода (извор у Биосци) (од непроменљивог придева ал „црвен”) и др.

Уколико бисмо прихватили етимолошку везу придева $p y \partial^{l}$ са придевом pyj овај списак бисмо могли да допунимо још неким важним подацима. У ужичком крају се налазио манастир Рујан, где је 1537 . год. штампано Рујанско четворојеванђеље. По биљци руј, у турско доба, велики део овог терена добио је назив Рујанска кнежина, која је ову област учинила препознатљивом по штављењу коже, тј. бојењу у црвено. Од микротопонима овде ћемо навести: Pујеваи (Севојно, десна страна Ђетиње), Рујево брдо (заселак Трнава), Рујевина (пашњак у Збојштици, река Дервента, десна притока Ђетиње), Рујевина (пашњак на Црвеним стенама у Жељинама), Рујева страна (Северово), Рујиште (заселак Забој, Гостиље, Златибор) и др.

Овакви примери су очигледна веза природе оронима, типа стене, типа земљишне подлоге и траве која на том терену расте, која, такође, може по својој физиономији да буде коврџава, па се може претпоставити да се у многим случајевима називи рудиница и рудача употребљавју управо за биљку руј.

4.2. Семантички кохезију, као што смо имали на примеру ороним ↔ трава, налазимо још и код квалитативног и колористичког одређења типа длаке код животиња, као у примерима рудоља, за вола (код Вука, СР) и рудан (у РУГ), и само квалитативног одређења типа вуне, у примеру руда овца (у ТДР). Кохезију налазимо и код врсте гљива и печурака. Тачно је да гљива може да буде црвена, па отуда именица рудюача (код Вука, СР), која је добила назив од глагола рудити „црвенети”, али је, такође, вероватно да су гљиве добијале своје називе и по текстури спора које су обично рошасте и извитоперене. А 
поред тога, такво етимолошко одређивање назива гљива везује их за придев $p y \partial^{2}$ „коврџав”, који у свом етимолошком деривационом пољу садржи и ороним утрина, влажно место окренуто југу, погодно за раст гљива и печурака. Као доказ тој хипотези нашли смо номинације за печурке рудишьача (код П. Скока), рудњача (и код П. Скока и код Вука, СР) и рудинарка (у РУГ). Још један интересантан податак је везан за печурке рудишьачу и рудњачу. У етимолошком речнику стоји значење да су то „печурке што расту по рудини, виловњаче”. Оне расту по рудишту, што је други назив за рудину, или вилинском вијалишту, где виле играју кола. Један од реквизита демонских бића јесу и отровне гљиве, а најпознатија међу њима јесте црвена мухара.

У исто време, глагол рудити шири своје семантичко поље са ,зрелих, румених воћки” (у РСГВ) и рудница „воћка чији су плодови тек зарудели” (у РУГ) на зору која свиће и ту се на оба семантичка поља допуњава са глаголским парњаком руменити. Глагол рудити у овом значењу (в. Веселиновићев пример, в. т. 3.4.) истискује из употребе прасловенски хомонимски глагол који је првобитно припадао придеву руд² и значио „коврџати” (в. Скок 1973: 166).

4.3. Придеви $p y \partial^{1}$ и $р у \partial^{2}$ даље творе, како смо напоменули (в. т. 2.4.), друге лексеме $р y c$, рујан и румен, које припадају истој граматичкој класи. Поставили смо питање сврсисходности њихове појаве. Придев рус је директан „потомак” ова два хомонимична придева и представља очигледан пример њихове семантичке и творбене кохезије, јер је он спецификовао своју употребу за длаку и то колористички одређену „црвеножуту или риђу”. У фолклору овај придев још увек живи у формулативном облику руса коса, ниске фреквентности употребе (3 за НП Вука I, 2 за ЕР). Придев рујан је, такође, спецификовао своју употребу у синтагми рујно вино и формулативно је високофреквентан у фолклору (15 за НП Вука I, 3 за ЕР), мада у савременом српском језику придев живи још у синтагми рујна зора, махом у поетској употреби. Једино од ова три придева широку дисперзију колокација има придев румен, мада и он зна да буде формулативно употребљен у синтагми румено лице, са ниским степеном формулативности (1 за НП Вука I, 0 за ЕР). Овде се њена формулативност оправдава богатим семантичким потенцијалом, који носи дата синтагма „лепа, здрава, једра, млада, сексуално зрела (девојка)" и има свог формулативног напоредног парњака, синтагму бело лице.

4.4. Овим радом смо показали судбину два прасловенска придева $p y \partial^{1}$, са колористичким, и $р y \partial^{2}$, са неколористичким значењем, са свом њиховом творбеном и семантичком дисперзијом. Да бисмо проучили све особености датих придева, поред неопходних етимолошких података, приказали смо и лексикографску и дијалектолошку грађу, као и географске факте. Контемплације значења поменутих придева су са синхроне перспективе присутне на великом броју примера. Један од примера је случај песме бр. 217 из Ерлангенског 
рукописа, где рудиница означава „култивисану башту са црвеном травом”. Контемплације сенантичких значења поменутих придева су присутне код номинација за траву, купус, печурке и називе домаћих животиња. Дешава се да, под утицајем свог хомонимског парњака, лексеме не морају више семантички да буду носиоци првобитног диференцијалног обележја, као што је случај са деривационим гнездом руда, рудник. Може да се деси да лексема толико развије свој семантички потенцијал, као нпр. глагол рудити (о зори) да потпуно истисне свог хомонимског парњака у значењу „коврџати”. Анализирани хомонимски придеви су у етимолошкој, семантичкој и творбеној повезаности са придевима $p y c, p y j$ и румен, који данас имају претежно фолклористичко обележје.

\section{ЛИТЕРАТУРА}

Безлај 1977: F. Bezlaj, Etimološki slovar slovenskoga jezika, Ljubljana: Institut za slovenski jezik SAZU.

Вук, СР: Вук Стефановић Караџић, Српски рјечник, треће државно издање, 1898.

Гортан Премк 1997: Д. Гортан-Премк, Полисемија, Београд: Институт за српски језик САНУ.

Драгићевић 2007: Р. Драгићевић, Полисемија српског језика, Београд: Завод за уџбенике.

EP: Г. Геземан, Ерлангенски рукопис старих српскохрватских народних песама, Сремски Карловци: Зборник за историју, језик и књижевност српскога народа.

НП Вук I: Вук Стефановић Караџић, Српске народне пјесме, Београд: Нолит, 1969.

Речник МС 1967-1976: Речник српскохрватскога књижевнога језика, I-VI, Нови Сад: Матица српска.

Речник САНУ 1959-: Речник српскохрватског књижевног и народног језика, Београд: Српска академија наука и уметности и Институт за српски језик САНУ.

РСГВ 2000-2010: Речник српских говора Војводине, свеска 1-10, Нови Сад: Матица српска.

РУГ 2014: Р. Цвијетић, Речник ужичког говора, Београд: ЈП Службени гласник, Универзитет у Крагујевцу - Учитељски факултет у Ужицу. 
Скок 1971-1974: P. Skok, Etimologijski riječnik hrvatskoga ili srpskoga jezika, Zagreb: Jugoslavenska akademija znanosti i umjetnosti.

Станић 2015: Д. Станић, Систем назива за боје у лирској народној поезији, необјављена докторска дисертација, Београд: Филолошки факултет.

Taфpa 1986: B. Tafra, Razgraničenje homonimije i polisemije (leksikološki i leksikografski problem), Filologija, 14, 381-393.

ТДР 2008: J. Динић, Тимочки дијалекатски речник, Београд: Институт за српски језик САНУ.

Шипка 1990: Д. Шипка, Лексичка хомонимија на примеру савременог српскохрватског стандардног језика, Сарајево: Институт за језик и књижевност.

\section{ABOUT THE RUDINICA (RUDIMENT) AND HOMONYMS OF TWO PROTO-SLAVIC ADJECTIVES IN THE SERBIAN LANGUAGE}

\section{Summary}

The paper has two homonymous adjectives, $r u d^{1}$ with coloristic meaning and $r u d^{2}$ with non-coloristic meaning, with polysemy „curly” and „loose, soft”. Based on etymologi$\mathrm{cal}$, lexicographical, dialectological, folkloristic and geographical data, we sought to show how semantic cohesion works among the derivatives of each of the individual homonyms, and how the adjective derivatives, under the influences of each other, get their present meanings. Common to both adjectives is that they do not have a large dispersion of nominations. Nominations are obtained by varying the small number of base models, which may be common to both adjectives. Both adjectives have found a foothold in both folk vocabulary and folklore. Crossing overmeanings of „curly” and „red” is the most obvious in folk names for grass, mushrooms, cabbage, domestic animals. Influenced by a homonymous couple, but also by a rival, the whole derivative base of ore, mine... was squeezed out of its original etymological baseof the adjective $r u d^{1}$ and approximated to the noncoloristic adjective $r u d^{2}$. Analyzed homonymic adjectives are etymologically, semantically and creatively related to the adjectives rus, ruj и rumen, which today have a predominantly folkloristic character. 